Article

\title{
Crosstalk of Nrf2 with the Trace Elements Selenium, Iron, Zinc, and Copper
}

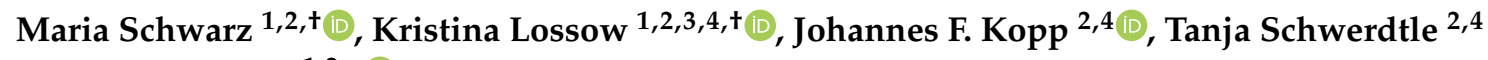 \\ and Anna P. Kipp 1,2,*(D) \\ 1 Department of Molecular Nutritional Physiology, Institute of Nutritional Sciences, \\ Friedrich Schiller University Jena, Dornburger Str. 24, 07743 Jena, Germany \\ 2 TraceAge-DFG Research Unit on Interactions of Essential Trace Elements in Healthy and Diseased Elderly, \\ D-13353 Potsdam-Berlin-Jena, Germany \\ 3 German Institute of Human Nutrition, Arthur-Scheunert-Allee 114-116, 14558 Nuthetal, Germany \\ 4 Department of Food Chemistry, Institute of Nutritional Science, University of Potsdam, \\ Arthur-Scheunert-Allee 114-116, 14558 Nuthetal, Germany \\ * Correspondence: anna.kipp@uni-jena.de; Tel.: +49-3641-949609 \\ + These authors equally contributed to the manuscript.
}

Received: 10 July 2019; Accepted: 23 August 2019; Published: 5 September 2019

\begin{abstract}
Trace elements, like $\mathrm{Cu}, \mathrm{Zn}, \mathrm{Fe}$, or Se, are important for the proper functioning of antioxidant enzymes. However, in excessive amounts, they can also act as pro-oxidants. Accordingly, trace elements influence redox-modulated signaling pathways, such as the Nrf2 pathway. Vice versa, Nrf2 target genes belong to the group of transport and metal binding proteins. In order to investigate whether Nrf2 directly regulates the systemic trace element status, we used mice to study the effect of a constitutive, whole-body Nrf2 knockout on the systemic status of $\mathrm{Cu}, \mathrm{Zn}, \mathrm{Fe}$, and Se. As the loss of selenoproteins under Se-deprived conditions has been described to further enhance Nrf2 activity, we additionally analyzed the combination of Nrf2 knockout with feeding diets that provide either suboptimal, adequate, or supplemented amounts of Se. Experiments revealed that the Nrf2 knockout partially affected the trace element concentrations of $\mathrm{Cu}, \mathrm{Zn}, \mathrm{Fe}$, or Se in the intestine, liver, and/or plasma. However, aside from $\mathrm{Fe}$, the other three trace elements were only marginally modulated in an Nrf2-dependent manner. Selenium deficiency mainly resulted in increased plasma $\mathrm{Zn}$ levels. One putative mediator could be the metal regulatory transcription factor 1 , which was up-regulated with an increasing Se supply and downregulated in Se-supplemented Nrf2 knockout mice.
\end{abstract}

Keywords: Nrf2; selenium; iron; copper; zinc; homeostasis

\section{Introduction}

Essential trace elements (TEs) are micronutrients with indispensable roles in enzymatic reactions, which consequently modify signaling pathways. The effects of TEs are mostly attributed to their redox-modulatory properties. TEs, such as $\mathrm{Cu}, \mathrm{Zn}$, and Fe but also Se, can act as pro-oxidants if present in excess or if available as free unbound ions. Otherwise, antioxidant and protective enzymes, such as the selenoproteins, glutathione peroxidases (GPX) and thioredoxin reductases (TXNRD) and also $\mathrm{Cu} / \mathrm{Zn}$ superoxide dismutase (SOD1), catalase, and metallothioneins (MT), depend on the supply with specific TEs. Via both ways, TEs have the potential to influence redox-modulated signaling pathways. Until now, many transcription factors have been shown to be sensitive towards the cellular redox status. Among them, nuclear factor erythroid 2 p45-related factor 2 (Nrf2) is a better characterized one [1].

Under basal conditions the transcription factor Nrf2 is kept in the cytosol by its binding partner, Kelch-like ECH-associated protein 1 (Keap1), which is anchored to the actin cytoskeleton and acts 
as a scaffold for the cullin3-dependent E3 ubiquitin ligase complex. After poly-ubiquitination, Nrf2 is degraded via the proteasome. There are several ways to induce the nuclear translocation and DNA binding of Nrf2. Of those, the best understood mechanism is the redox-dependent modification of thiol groups in the Keap1 protein, which results in a conformational change locking Nrf2 at Keap1. Newly synthesized Nrf2 can no longer be degraded and translocates to the nucleus. Besides Keap1, caveolin 1, the ubiquitin ligase Skp, cullin, F-box containing complex (SCF), and the retinoid $\mathrm{X}$ receptor $\alpha(\mathrm{RXR} \alpha)$ also interact with and repress Nrf2. Nrf2 target genes contain so-called antioxidant-responsive elements (ARE) within their promoter regions (reviewed in [2]). The list of Nrf2-regulated genes is further increasing continuously and comprises genes involved in antioxidant defense, NADPH regeneration, glutathione synthesis, and drug detoxification, as well as in metabolic control, including carbohydrate and lipid metabolism [3]. Nrf2 has previously been shown to be modulated by changes in the cellular status of single TEs, e.g., Zn. Zn binding triggers a conformational switch in the cullin3 substrate adaptor function of Keap1, thus Nrf2 becomes stabilized and can activate the transcription of target genes [4]. Furthermore, $\mathrm{Zn}$ modulates the activity of several kinases and phosphatases, which accordingly enhances Nrf2 activity (Table 1).

Vice versa, Nrf2 target genes belong to the group of selenoproteins or are involved in regulating the systemic TE status (Table 1). This has already been studied for Fe [3]. In mice, Nrf2 is activated in response to increased hepatic Fe levels [5]. Accordingly, Nrf2 protects the murine liver against the toxicity of dietary Fe overload by preventing cell death of hepatocytes and enhancing Fe release [6]. During inflammation, Nrf2 induces ferroportin (Fpn1), the sole Fe exporter, to enhance Fe efflux from macrophages or enterocytes [7]. Several Fe transport and binding proteins, like Fpn1, hepcidin (Hamp), and ferritin, are Nrf2 target genes [8]. In addition, key enzymes of heme biosynthesis are induced via Nrf2 (Table 1). Altogether, this battery of proteins reduces the pool of free intracellular Fe. A comparable approach is the upregulation of MTs, a family of cysteine-rich proteins that bind Zn and $\mathrm{Cu}$ via their thiol groups [9]. Another important mediator of $\mathrm{Cu}$ homeostasis is the $\mathrm{Cu}$-transporting ATPase 2 (Atp7b), the Wilson's ATPase. Being primarily expressed in hepatocytes, Atp7b supports the incorporation of $\mathrm{Cu}$ into ceruloplasmin $(\mathrm{Cp})$ and enhances the excretion of $\mathrm{Cu}$ from the liver into the bile $[10,11]$.

Table 1. Effects of single trace elements on Nrf2 signaling (overview in [12]).

\begin{tabular}{clc}
\hline TE & \multicolumn{1}{c}{ Nrf2 Pathway Activity } & TE-Related Nrf2 Target Genes \\
\hline $\mathrm{Cu}$ & $\begin{array}{l}\mathrm{CuCl}_{2} \text { activates Nrf2; } \\
\mathrm{Nrf2} \text { is crucial for MRE/ARE-mediated transcription } \\
\text { in response to Cu [13] }\end{array}$ & MT1/2, SOD1 \\
\hline $\mathrm{Fe} \quad \begin{array}{l}\text { cytotoxic concentrations of Fe activate Nrf2 in } \\
\text { murine primary astrocytes [14] and hepatocytes [6] }\end{array}$ & $\begin{array}{l}\text { Fpn1, heme oxygenase (Hmox1) [15], } \\
\text { hamp, ferritin (FTH-1, FTL) [16], } \\
\text { ferrochelatase (Fech), biliverdin } \\
\text { reductases (BlvrA/B) }\end{array}$ \\
\hline $\mathrm{Se} \quad \begin{array}{l}\text { a suboptimal Se status activates Nrf2 in mice [17]; } \\
\text { high selenite concentrations enhance Nrf2 target } \\
\text { gene expression [18] }\end{array}$ & $\begin{array}{l}\text { GPX2 [19], TXNRD1 [20] } \\
\text { Zn upregulates Nrf2 function, e.g., } \\
\text { via phosphorylation signals [21] }\end{array}$ & MT1/2, SOD1 \\
\hline
\end{tabular}

There is substantial cross-talk between Nrf2 and other transcription factors, including the aryl hydrocarbon receptor (AhR), nuclear factor $k$-light-chain-enhancer of activated B cells (NF-kB), tumor suppressor protein $\mathrm{p} 53$, and Notch making Nrf2, an important factor in regulating immune defense, differentiation, and tissue regeneration, as well as cell death [22]. Another interesting interaction could take place with the metal regulatory transcription factor 1 (MTF1), which senses Cu and $\mathrm{Zn}$ and binds to metal-responsive elements (MREs) in the promoter of target genes. These include 
the zinc transporter solute carrier family 30 member 1 Slc30A1, encoding for ZnT1, as well as MT1 and 2, but also selenoproteins, like Selenoh, Selenow, and TXNRD2, modulators of the Fe status, like Fpn1 and Hamp [23], and Atp7b [24]. In particular, MT genes often contain AREs next to MREs and are activated via Nrf family members. For MT1, this activation has been shown by Nrf1 as well as by Nrf2, especially in response to the cellular Zn status, albeit to a smaller extent [25]. Thus, MTF1 could be a potential link between Nrf2 signaling and regulation of TE homeostasis.

In most previous studies, the authors focused on high concentrations and pro-oxidant effects of overloading single TEs, e.g., Se. However, we have previously shown that Nrf2 becomes activated under conditions of a suboptimal Se status in the duodenum [17] and liver [26] of mice. NAD(P)H quinone dehydrogenase 1 (NQO1) activity was analyzed as one of the most strongly regulated target genes of Nrf2. Most probably, the Nrf2 activation is an attempt to compensate for the reduced expression of antioxidant selenoproteins. This condition has a much higher physiological relevance than Se supplementation because of the suboptimal nutritional Se supply prevailing in Europe [27]. The U-shaped effect on Nrf2 activity observed for Se could also be true for other TEs; however, this has not been studied systematically so far.

Based on the results obtained for single TEs, we aimed to study the effect of a whole-body Nrf2 knockout $(\mathrm{KO})$ in mice on the systemic TE status of $\mathrm{Fe}, \mathrm{Se}, \mathrm{Cu}$, and $\mathrm{Zn}$. A suboptimal Se status results in limited expression of Se-sensitive selenoproteins. As reduced expression of selenoproteins, such as TXNRD1, under Se-deprived conditions further enhances Nrf2 activity [28], we also studied the combination of $\mathrm{Nrf2} \mathrm{KO}$ mice with feeding diets that provide either a suboptimal, adequate, or supplemented amount of Se. Focusing only on wild type (WT) mice with different Se statuses allowed the question of whether changes in a single TE (in this case Se) affect the homeostasis of three other TEs to be addressed. In addition to markers for the TE status, TE-related Nrf2 target genes were analyzed in the liver of those mice.

\section{Materials and Methods}

\subsection{Animal Experiment}

Animal experiments were approved by the ethics committee of the Ministry of Agriculture and Environment (State Brandenburg, Germany) and all methods were carried out in accordance to permission number V3-2437-29-2012. Nrf2 KO mice on a C57BL/6J background were kindly provided by Masayuki Yamamoto (Tohoku University Graduate School of Medicine) and genotyped as previously described [29]. Adult male and female mice were used for the animal experiments that were group-housed and random-caged with ad libitum access to a standard chow diet (Ssniff, Soest, Germany, Table 2), with an Se content of $0.3 \mathrm{mg} / \mathrm{kg}$ diet, deionized water, $23^{\circ} \mathrm{C}$, and a $12: 12 \mathrm{~h}$ dark:light cycle. Those mice were sacrificed at an age of 6 months.

Table 2. Estimated trace element requirements of mice [30] and trace elements in the diets used.

\begin{tabular}{cccc}
\hline TE & Requirement $(\mathbf{m g} / \mathbf{k g})$ & $\begin{array}{c}\text { Chow (Ssniff) } \\
(\mathbf{m g} / \mathbf{k g})\end{array}$ & Altromin C1045 (mg/kg) \\
\hline $\mathrm{Cu}$ & 6 & 8.8 & 2.7 \\
$\mathrm{Fe}$ & 35 & 215 & 151 \\
$\mathrm{Se}$ & 0.15 & 0.3 & 0.03 \\
$\mathrm{Zn}$ & 10 & 97 & 57 \\
\hline
\end{tabular}

In the second experiment, male WT and Nrf2 KO mice were weaned onto a diet based on torula yeast (Altromin C1045; Lage, Germany, Table 2) with a low basal selenium content of $0.03 \mathrm{mg} / \mathrm{kg}$. For the selenium adequate $(+\mathrm{Se})$ and the supplemented $(++\mathrm{Se})$ diets, the basal chow was enriched with L (+)-selenomethionine (Fisher Scientific, Schwerte, Germany) to a final selenium content of 0.15 or $0.6 \mathrm{mg} / \mathrm{kg}$, respectively. The $\mathrm{Se}, \mathrm{Fe}, \mathrm{Cu}$, and $\mathrm{Zn}$ concentration of the diets was measured by 
ICP-MS/MS. Diets were fed for 6 weeks until an age of 10 weeks before mice were anesthetized by isoflurane (Abbot, Wiesbaden, Germany), and blood was withdrawn by heart puncture. Plasma was obtained after centrifugation of the blood for $15 \mathrm{~min}\left(1200 \times \mathrm{g}\right.$ and $\left.4{ }^{\circ} \mathrm{C}\right)$.

\subsection{ICP-MS/MS Analysis of TE}

Frozen tissue (liver or duodenum) was pulverized using a TissueLyser (Qiagen, Hilden, Germany) for $2 \times 30 \mathrm{~s}$ at maximum speed. Feed samples were pulverized by mortar and pestle. About $50 \mathrm{mg}$ of each sample were weighed precisely into polytetrafluoroethylene (PTFE) microwave vessels. For mouse tissue, the variance was found to be far below $5 \%$ between replicates of the same mouse (data not shown); therefore, only one replicate was analyzed to preserve tissue for other experiments. However, in the case of obvious outliers, the sample was digested and analyzed again. Due to high in-batch variance in the chow diets from some manufacturers, at least three independent replicates were prepared in the case of feed samples. For tissue samples, $1000 \mu \mathrm{L}$ of concentrated $\mathrm{HNO}_{3}(65 \%$, suprapure, Merck, Darmstadt, Germany), $50 \mu \mathrm{L}$ of a solution containing $100 \mu \mathrm{g} \mathrm{Rh} / \mathrm{L}$ (made from $10 \mathrm{mg} / \mathrm{L}$ single-element stock solution, Carl Roth, Karlsruhe, Germany) as the internal standard, and $950 \mu \mathrm{L}$ ultrapure water were added. For feed samples, $900 \mu \mathrm{L}$ of concentrated $\mathrm{HNO}_{3}, 250 \mu \mathrm{L}$ of $\mathrm{H}_{2} \mathrm{O}_{2}$ (30\%, Merck/Sigma-Aldrich, Darmstadt, Germany), and $810 \mu \mathrm{L}$ of ultrapure water were added. In addition, $20 \mu \mathrm{L}$ of a solution containing $1000 \mu \mathrm{g} \mathrm{Rh} / \mathrm{L}$ and $20 \mu \mathrm{L}$ of $10,000 \mu \mathrm{g}{ }^{77} \mathrm{Se} / \mathrm{L}$ (made from a $10,000 \mathrm{mg} / \mathrm{L}$ stock solution, prepared from isotopically enriched ${ }^{77} \mathrm{Se}\left(97.20 \pm 0.20 \%{ }^{77} \mathrm{Se} ; 0.10 \%{ }^{74} \mathrm{Se}\right.$; $0.40 \pm 0.10 \%{ }^{76} \mathrm{Se} ; 2.40 \pm 0.10 \%{ }^{78} \mathrm{Se} ; 0.10 \%{ }^{80} \mathrm{Se} ; 0.10 \%{ }^{82} \mathrm{Se}$ as certified by Trace Sciences International, ON, Canada), purchased from Eurisotop SAS (Saarbrücken, Germany), were added as internal standard or isotope dilution standard, respectively. The samples were then digested in a Mars 6 microwave digestion system (CEM, Kamp-Lintfort, Germany) by heating to $200{ }^{\circ} \mathrm{C}$ over a period of $10 \mathrm{~min}$ and holding this temperature for $20 \mathrm{~min}$. In each digestion, two blank samples and $50 \mathrm{mg}$ of certified reference material ERM-BB 422 (fish muscle) or ERM BB 186 (pig kidney, Merck/Sigma-Aldrich) were carried along to ensure accuracy of results. Samples were repeated if the recovery for any analyzed element deviated by more than $10 \%$ from the reference value and/or was outside the error range of the material. After digestion, samples were quantitatively transferred to $15-\mathrm{mL}$ polypropylene tubes combined with two times $475 \mu \mathrm{L}$ (tissue) or $1 \mathrm{~mL}$ (feed) of ultrapure water from vessel rinsing. The samples were kept at $4{ }^{\circ} \mathrm{C}$ until one day prior to measurement, when they were further diluted $1+4$ in 15-mL polypropylene tubes to give a final concentration of $2.93 \% \mathrm{HNO}_{3}$, as well as either $2.5 \mu \mathrm{g}$ $\mathrm{Rh} / \mathrm{L}$ (tissue) or $1 \mu \mathrm{g} \mathrm{Rh} / \mathrm{L}$ and $10 \mu \mathrm{g}{ }^{77} \mathrm{Se} / \mathrm{L}$ (feed). Mixed-element calibration standards were made to match the concentration of $\mathrm{HNO}_{3}$ and the internal standard in the diluted digests from $1000 \mathrm{mg} / \mathrm{L}$ single-element stock solutions (Carl Roth). Calibration ranges were Fe: 5-1000 $\mu \mathrm{g} / \mathrm{L}, \mathrm{Cu}: 0.5-100 \mu \mathrm{g} / \mathrm{L}$, Zn: $2.5-500 \mu \mathrm{g} / \mathrm{L}$, Se: $0.05-10 \mu \mathrm{g} / \mathrm{L}$. For Se isotope dilution analysis (IDA), a solution containing $10 \mu \mathrm{g}$ ${ }^{77} \mathrm{Se} / \mathrm{L}$, as well as a $1+1$ mixture of $10 \mu \mathrm{g}{ }^{77} \mathrm{Se} / \mathrm{L}$ and $10 \mu \mathrm{g}$ naturally distributed Se/L was prepared. Solutions were then analyzed via ICP-MS/MS (8800 ICP-QQQ-MS, Agilent Technologies, Waldbronn, Germany at $1550 \mathrm{~W}$ plasma Rf power, equipped with Ni-cones, MicroMist nebulizer at $1.2 \mathrm{~L} \mathrm{Ar} / \mathrm{min}$ and Scott-type spraychamber) monitoring the following mass to charge ratios (Q1 $\rightarrow \mathrm{Q} 2)$ : He-mode: Fe $(56 \rightarrow 56), \mathrm{Cu}(63 \rightarrow 63), \mathrm{Zn}(66 \rightarrow 66), \mathrm{Rh}(103 \rightarrow 103) ; \mathrm{O} 2-m o d e:$ Se $(77 \rightarrow 93)$, Se $(80 \rightarrow 96), \mathrm{Rh}(103 \rightarrow 103)$. Elements in He-mode were determined via external calibration after internal standard correction using $\mathrm{Rh}$ and Se was also determined either via external calibration (tissue) or via isotope dilution analysis (IDA) (feed) as described previously [31]. The instrument was optimized on a daily basis for maximum sensitivity across the relevant mass range (He: Co $(59 \rightarrow 59), \mathrm{Y}(89 \rightarrow 89), \mathrm{Tl}(205 \rightarrow 205)$; O2: Co $(59 \rightarrow 59)$, $\mathrm{Y}(89 \rightarrow 95), \mathrm{Tl}(205 \rightarrow 205))$, an oxide ratio of $<1.5 \%\left({ }^{156}(\mathrm{CeO})^{+} /{ }^{140} \mathrm{Ce}^{+}\right)$, and a doubly charged ratio of $<2 \%\left({ }^{140} \mathrm{Ce}^{2+} /{ }^{140} \mathrm{Ce}^{+}\right)$, as well as a background of $<0.1 \mathrm{CPS}$ prior to measurement.

The applied method for the analysis of TEs in murine plasma has been described previously [32]. In brief, $50 \mu \mathrm{L}$ of murine plasma were diluted $1+9$ with a dilution mix ( 5 vol.- $\%$ butanol $(99 \%$, Alfa Aesar, Karlsruhe, Germany), 0.05 m.- \% Na-EDTA (Titriplex ${ }^{\circledR}$ III, pro analysis, Merck), 0.05 vol.-\% Triton $^{\mathrm{TM}}$ X-100 (Merck Sigma-Aldrich), and 0.25 vol.- $\%$ ammonium hydroxide (puriss. p.a. plus, $25 \%$ in 
water, Fluka, Buchs, Germany)), as well as internal standards (final concentrations: $1 \mu \mathrm{g} \mathrm{Rh} / \mathrm{L}$ and $30 \mu \mathrm{g}$ ${ }^{77} \mathrm{Se} / \mathrm{L}$ ). The diluted sample was then subjected to analysis for $\mathrm{Fe}, \mathrm{Cu}, \mathrm{Zn}$, and Se (IDA) via ICP MS/MS.

\subsection{RNA Isolation, Reverse Transcription, and Quantitative Real-Time PCR}

The mRNA was isolated from frozen and pulverized (TissueLyser; Qiagen) tissues with the Dynabeads mRNA DIRECT Kit (Life Technologies, Fisher Scientific) according to the manufacturer's protocol. Reverse transcription (RT) was performed with $150 \mathrm{ng}$ mRNA, 0.15 pmol oligo(dT)15 primers, $1 \times$ RT buffer, $700 \mu \mathrm{M}$ dNTPs, $0.1 \mathrm{mg} / \mathrm{mL}$ BSA, 30 U RNasin ${ }^{\circledR}$ (Promega, Mannheim, Germany), and $180 \mathrm{U}$ Moloney murine leukemia virus reverse transcriptase (M-MLV RT, Promega) in a total volume of $45 \mu \mathrm{L}$. Real-time PCR was performed in a total volume of $25 \mu \mathrm{L}$ with $1 \mu \mathrm{L}$ of $1+9$ diluted cDNA measured in triplicates using a Mx3005P QPCR System (Agilent). SYBR Green I (Molecular Probes, Eugene, OR, USA) served as the fluorescent reporter. The annealing temperature was $60{ }^{\circ} \mathrm{C}$ for all PCR reactions and specificity was confirmed by a melting curve analysis. All PCR products were quantified with a standard curve to correct for differences in PCR efficiencies. Primer sequences (Sigma-Aldrich, Steinheim, Germany) are listed in Table 3. A normalization factor was calculated from the two reference genes, Epcam and Rpl13a, and used for normalization.

Table 3. Primer sequences $\left(5^{\prime} \rightarrow 3^{\prime}\right)$.

\begin{tabular}{|c|c|c|}
\hline Gene & RefSeq-ID & Sequence \\
\hline Atp7b, ATPase copper transporting beta & NM_007511.2 & $\begin{array}{l}\text { CAGATGTCAAAGGCTCCCATTCAG } \\
\text { CCAATGACGATCCACACCACC }\end{array}$ \\
\hline Cp, ceruloplasmin & NM_001276248.1 & $\begin{array}{l}\text { GTACTACTCTGGCGTTGACCC } \\
\text { TTGTCTACATCTTTCTGTCTCCCA }\end{array}$ \\
\hline DMT1, divalent metal transporter 1 & NM_001146161.1 & $\begin{array}{l}\text { CTCAGCCATCGCCATCAATCTC } \\
\text { TTCCGCAAGCCATATTTGTCCA }\end{array}$ \\
\hline Epcam, epithelial cell adhesion molecule & NM_008532.2 & $\begin{array}{l}\text { TCATCGCTGTCATTGTGGTGGT } \\
\text { TCACCCATCTCCTTTATCTCAGCC }\end{array}$ \\
\hline Fpn1, ferroportin & NM_016917.2 & $\begin{array}{l}\text { CTGGTGGTTCAGAATGTGTCCGT } \\
\text { AGCAGACAGTAAGGACCCATCCA }\end{array}$ \\
\hline Fth1, ferritin heavy polypeptide 1 & NM_010239.2 & $\begin{array}{l}\text { CGCCAGAACTACCACCAGGA } \\
\text { TTCTTCAGAGCCACATCATCTCGG }\end{array}$ \\
\hline Hamp, hepcidin & NM_032541.1 & $\begin{array}{l}\text { AAGCAGGGCAGACATTGCGA } \\
\text { TGCAACAGATACCACACTGGGA }\end{array}$ \\
\hline MT2, metallothionein 2 & NM_008630.2 & $\begin{array}{l}\text { CTGTGCCTCCGATGGATCCT } \\
\text { CTTGTCGGAAGCCTCTTTGCAG }\end{array}$ \\
\hline NQO1, NAD(P)H quinone dehydrogenase 1 & NM_008706.4 & $\begin{array}{l}\text { ATGTACGACAACGGTCCTTTCCAG } \\
\text { GATGCCACTCTGAATCGGCCA }\end{array}$ \\
\hline Rpl13a, ribosomal protein L13a & NM_009438.5 & $\begin{array}{l}\text { GTTCGGCTGAAGCCTACCAG } \\
\text { TTCCGTAACCTCAAGATCTGCT }\end{array}$ \\
\hline Selenow, selenoprotein $\mathrm{W}$ & NM_009156.2 & $\begin{array}{l}\text { ATGCCTGGACATTTGTGGCGA } \\
\text { GCAGCTTTGATGGCGGTCAC }\end{array}$ \\
\hline Tfrc, transferrin receptor & NM_011638.4 & $\begin{array}{l}\text { GGCTGAAACGGAGGAGACAGA } \\
\text { CTGGCTCAGCTGCTTGATGGT }\end{array}$ \\
\hline Zip14, solute carrier family 39 member 14 & NM_001135151.1 & $\begin{array}{l}\text { GCCTCACCATCCTGGTATCCGT } \\
\text { AGCAGACGAGGCATGAGTCTGG }\end{array}$ \\
\hline
\end{tabular}

\subsection{ELISA}

Ferritin and transferrin were measured in plasma samples using Mouse Ferritin and Transferrin ELISA (ALPCO, Salem, MA, USA) following the manufacturer's instruction. Therefore, plasma samples were either diluted 1:20 or 1:200,000, respectively. 


\subsection{Western Blot}

To obtain protein lysates, frozen liver samples were homogenized in Tris buffer (100 mM Tris, $300 \mathrm{mM} \mathrm{KCl}$, pH 7.6 with 0.1\% Triton X-100 (Serva, Heidelberg, Germany)) using a TissueLyser (Qiagen) for $2 \times 30 \mathrm{~s}$ at maximum speed. Cellular debris was removed by centrifugation $(14,000 \times g, 15 \mathrm{~min}$, $4{ }^{\circ} \mathrm{C}$ ) and protein concentrations were determined by Bradford analysis (Biorad, München, Germany). After SDS polyacrylamide gel electrophoresis, gels were immunoblotted to nitrocellulose and blots were blocked in 5\% non-fat dry milk in Tris-buffered saline containing $0.1 \%$ Tween 20 at room temperature for $1 \mathrm{~h}$. The following antibodies were used: Rabbit anti-Ferritin-H (151023, Abcam, Cambridge, UK; 1:500), rabbit anti-MT (192385, Abcam; 1:1000), rabbit anti-Ctr1 (129067, Abcam; 1:2000), rabbit anti-MTF-1 antibody (86380, Novus Biologicals, Centennials, US; $1: 250)$, and rabbit anti- $\beta$-Actin (8227, Abcam; 1:10,000). Horseradish peroxidase-conjugated goat anti-rabbit IgG (Chemicon, Hofheim, Germany; $1: 50,000)$ served as secondary antibody. Intensities of identified bands were quantified densitometrically with the Luminescent Image Analyzer LAS-3000 system (Fujifilm, Tokyo, Japan). Protein expression was normalized to $\beta$-actin expression or Ponceau staining.

\subsection{Enzyme Activities}

Protein lysates were prepared as described in the section 'Western Blot'. Measurements of NQO1 [17], TXNRD [33], GPX [34], and glutathione S transferase (GST) [35] activities have been described previously. Briefly, NQO1 activity was examined by a menadione-mediated reduction of 3-(4,5-dimethylthiazol-2-yl)-2,5-diphenyltetrazolium bromide (MTT). TXNRD activity was measured by the NADPH-dependent reduction of 5,5'-dithiobis (2-nitrobenzoic acid) (DTNB). GPX activity was determined in an NADPH-consuming glutathione reductase coupled assay. GST activity was conducted using 1-chloro-2,4-dinitrobenzene $(\mathrm{CDNB})$ as substrate in the presence of reduced glutathione. All measurements were performed in triplicates using 96-well plates and a microplate reader (Synergy2, BioTek, Bad Friedrichshall, Germany).

\subsection{Statistics}

Data are shown as mean + SD. Statistical significance was calculated by GraphPad Prism version 5 (San Diego, CA, USA) using two-way analysis of variance (ANOVA) with Bonferroni's post-test as indicated in the figure legends. A $p$-value below 0.05 was considered statistically significant.

\section{Results}

To address the question of whether Nrf2 not only modulates the status of single TEs, such as Fe, but also of several TEs in parallel, we analyzed $\mathrm{Se}, \mathrm{Fe}, \mathrm{Cu}$, and $\mathrm{Zn}$ in male and female Nrf2 KO mice fed a standard chow diet. TE concentrations were assessed in the intestine, liver, and plasma. Fe was retained more in the liver and small intestine of Nrf2 KO than in WT mice (Figure 1A,B). Consequently, plasma Fe levels were reduced but only in female mice (Figure 1C).

No changes were observed concerning the Fe markers, ferritin and transferrin (Figure S1A,B). In parallel, intestinal Se (Figure 1D) and Zn (Figure 1G) concentrations were reduced in Nrf2 KO compared to WT mice. This was also partially reflected in the Se and Zn plasma and liver values but less consistently. Nrf2-mediated changes of the $\mathrm{Cu}$ status appear to be sex specific as only female mice showed lower plasma Cu levels upon loss of Nrf2 (Figure 1L). Overall, Nrf2 reduced the systemic Fe status but increased Se and Zn. Female WT mice had higher plasma levels of Fe, Zn, and Cu. In the liver, amounts of Fe and Se were increased in female mice. In general, chow diets contain high amounts of all TEs, usually at least twice the recommended amounts. Thus, Nrf2-modulated effects might be more pronounced under conditions of limited TE access.

To analyze the role of the Se status on other TEs in combination with loss of Nrf2, both WT and Nrf2 $\mathrm{KO}$ mice were weaned onto one of three diets containing suboptimal $(0.03 \mathrm{ppm})$, adequate $(0.15 \mathrm{ppm})$, or supplemented $(0.6 \mathrm{ppm})$ amounts of Se. The experimental set-up was chosen according to previous 
feeding experiments to efficiently reduce the Se status in the -Se group. For better comparability with previous experiments, only male mice were studied [17]. In addition, the remaining three TEs were reduced in the torula yeast-based diet as compared to the chow diet (Table 2).
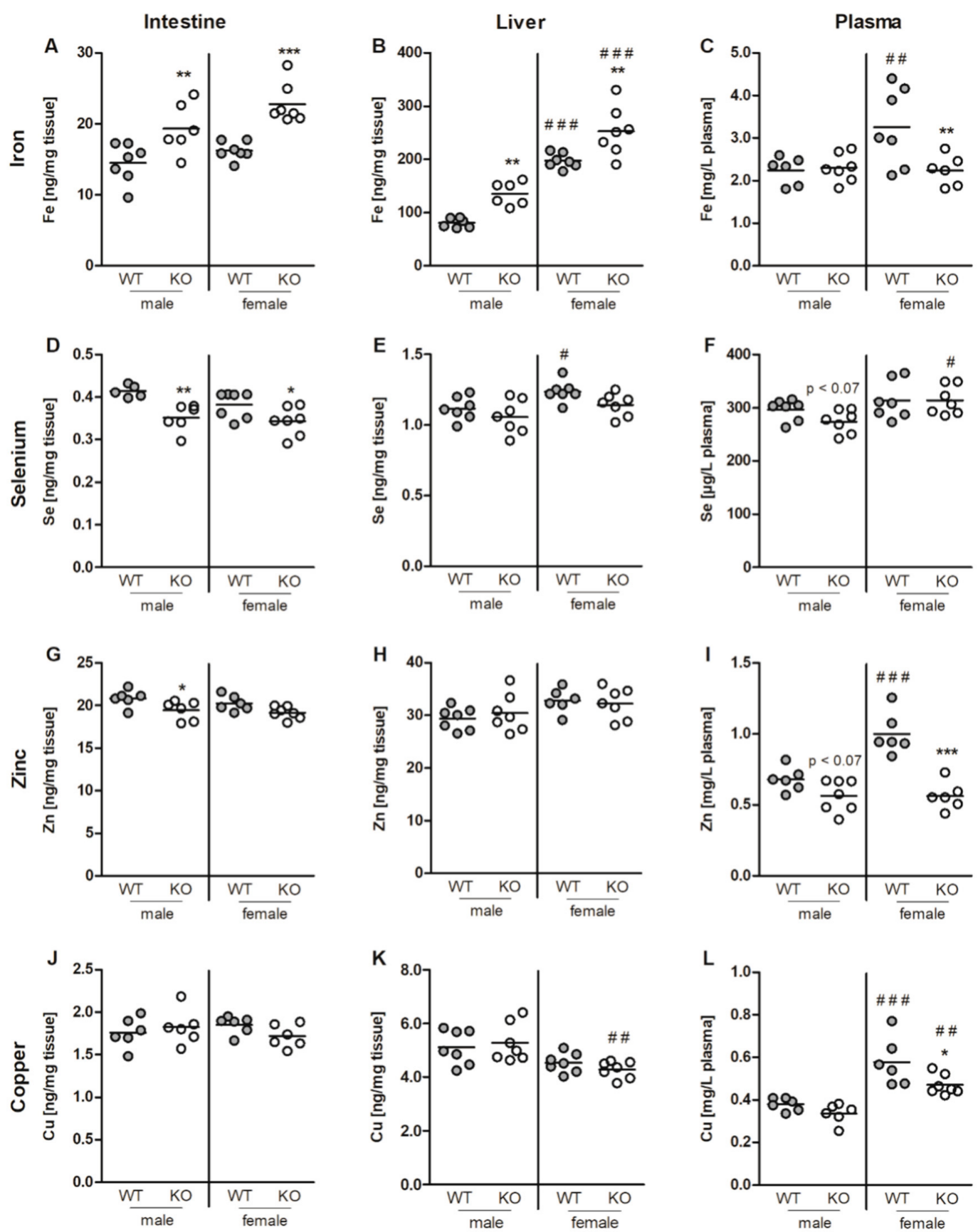

Figure 1. Fe (A-C), Se (D-F), Zn (G-I), and $\mathrm{Cu}(\mathrm{J}-\mathrm{L})$ concentrations in the jejunum $(\mathbf{A}, \mathbf{D}, \mathrm{G}, \mathrm{J})$, liver (B,E,H,K), and plasma (C,F,I,L) of six-month-old male and female Nrf2 KO and WT mice fed a standard chow diet with $0.3 \mathrm{ppm}$ Se. The TE profile was analyzed using ICP-MS/MS. Scatter dot plots with mean $(n=6-7)$. ${ }^{*} p<0.05 ;{ }^{* *} p<0.01 ;{ }^{* * *} p<0.001$ vs. WT and ${ }^{\#} p<0.05$; ${ }^{\# \#} p<0.01$; ${ }^{\# \#} p<0.001$ vs. male (two-way ANOVA with Bonferroni's post-test).

As expected, the dietary approach successfully modulated the Se status of the different feeding groups (Figure 2A,B). The Se content of the chow diet fed in experiment one was $0.3 \mathrm{ppm}$ and thus between the amount of the $+\mathrm{Se}(0.15 \mathrm{ppm})$ and the $++\mathrm{Se}(0.6 \mathrm{ppm})$ diets. Comparing the plasma Se content in both experiments (Figures $1 \mathrm{~F}$ and $2 \mathrm{~A}$ ) revealed that the +Se diet with $0.15 \mathrm{ppm}$ was 
already able to set the plasma Se concentration to almost $300 \mu \mathrm{g} / \mathrm{L}$, which was nearly the same amount as measured in the 0.3 (Figure 1F) or $0.6 \mathrm{ppm}$ Se groups (++Se, Figure $2 \mathrm{~A})$.

A

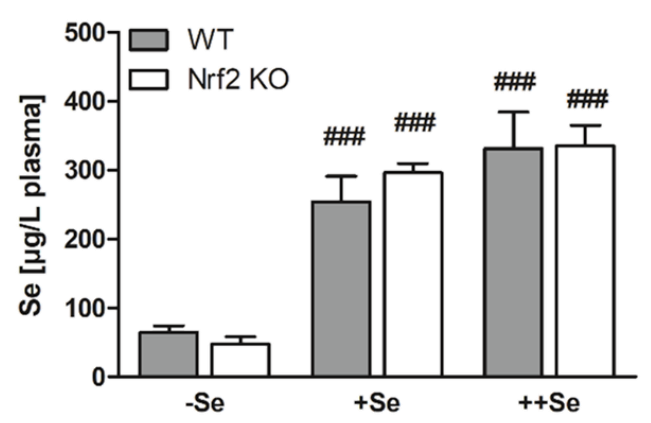

C

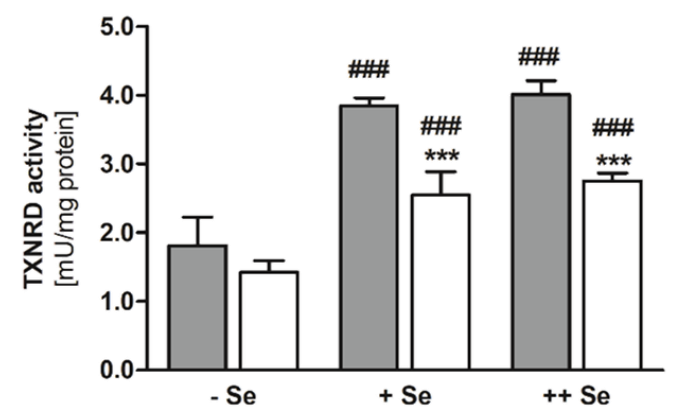

E

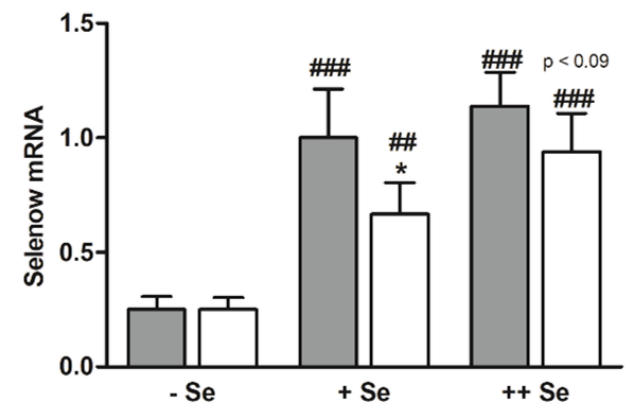

B



D



Figure 2. Biomarkers of the Se status. Se concentrations in the plasma (A) and liver (B) of Nrf2 KO and WT male mice fed diets with defined Se contents (-Se: 0.03 ppm; +Se: 0.15 ppm; ++Se: 0.6 ppm). The TE profile was analyzed using ICP-MS/MS. Enzyme activity of TXNRD (C) and GPX (D) was analyzed together with mRNA expression of Selenow (E) from liver samples of male Nrf2 KO and WT mice. Bars represent means + SD $(n=4-5) .{ }^{*} p<0.05 ;{ }^{* * *} p<0.001$ vs. WT and ${ }^{\# \#} p<0.01$; ${ }^{\# \#} p<0.001$ vs. -Se (two-way ANOVA with Bonferroni's post-test).

In order to confirm that loss of Nrf2 resulted in diminished expression of classical Nrf2 target genes, NQO1 activity (Figure 3A) was analyzed. Enzyme activity was substantially decreased in Nrf2 KO mice. Basal NQO1 mRNA levels were much higher in female than in male mice (Figure S1C). To our surprise, NQO1 activity was not increased under -Se conditions but was significantly decreased in comparison to the $+\mathrm{Se}$ or $++\mathrm{Se}$ groups. In Nrf2 KO mice, no Se-dependent effect was detectable. Comparable results were obtained for total GST activity (Figure 3B). 
A

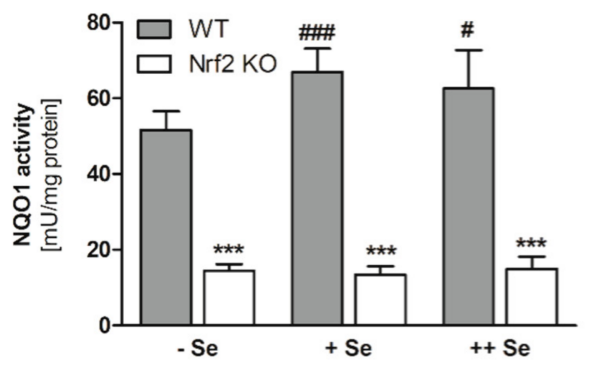

B

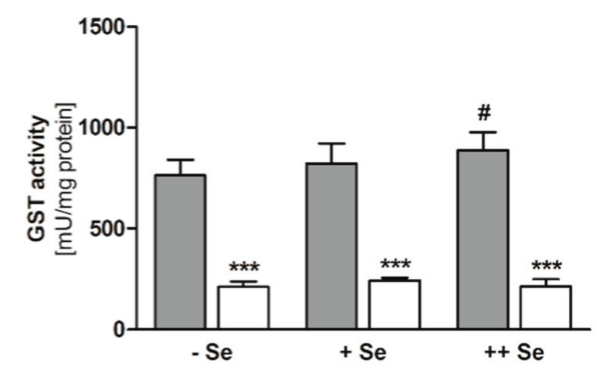

Figure 3. Hepatic enzyme activities as markers for Nrf2 activity. The Nrf2 target gene NQO1 was measured by an activity assay (A). Total enzyme activity of all GST isoforms was measured by an activity assay (B). Samples were the liver of Nrf2 KO and WT male mice fed diets with defined Se contents (-Se: 0.03 ppm; +Se: 0.15 ppm; ++Se: 0.6 ppm). Bars represent means + SD $(n=4-5) .{ }^{* * *} p<0.001 \mathrm{vs.} \mathrm{WT}$ and ${ }^{\#} p<0.05 ;{ }^{\# \#} p<0.001$ vs. - Se (two-way ANOVA with Bonferroni's post-test).

Besides Nrf2 target genes, selenoprotein expression was also studied. Classical biomarkers of the murine Se status, such as TXNRD and GPX activity, already reached a plateau in the +Se groups and could not be further increased by the ++ Se supply (Figure 2C,D). Total TXNRD activity was reduced in Nrf2 KO mice, because TXNRD1 expression is regulated via Nrf2 (Figure 2C). Total hepatic GPX activity, mainly reflecting GPX1 activity, was not affected by the loss of Nrf2 (Figure 2D). Under certain conditions, selenoprotein mRNAs could also serve as biomarkers of the Se status, which is the case for Selenow, showing a four-fold increase in the Se-treated groups in comparison to the -Se group (Figure 2E). Under + Se conditions, Selenow expression was significantly lower in Nrf2 KO than in WT mice and in the ++ Se groups there was a trend $(p<0.09$; Figure 2E). Together with a small reduction of the hepatic Se content, this might indicate that the Se status is lower in Nrf2 KO than in WT mice.

As shown before (Figure $1 \mathrm{C}$ and Figure S1A,B), Fe, ferritin, and transferrin plasma levels were unaffected by Nrf2 in male mice (Figure $4 \mathrm{~A}-\mathrm{C}$ ). In addition, all three parameters were independent of the Se status. The increased Fe tissue retention described under chow diet conditions (Figure 1) was only significant under-Se conditions in the liver in this case (Figure 4D). To study putative mechanisms for the observed Fe accumulation in the liver, the expression of different Fe-related genes/proteins were tested.

First, we tested Hamp expression in the liver, because Hamp is the major regulator of Fe homeostasis, which is upregulated in response to an increase in Fe levels. Recently, it has been shown that this upregulation is partially impaired in Nrf2 KO livers [36]. Herein, we could not observe an upregulation in -Se Nrf2 KO livers (Figure 4E). Hamp is known to limit the expression of the Fe exporter Fpn1 in the intestine to reduce systemic Fe levels. Indeed, Fpn1 expression was reduced in the duodenum of both $-\mathrm{Se}$ and $++\mathrm{Se} \mathrm{Nrf2} \mathrm{KO}$ mice (Figure $4 \mathrm{~F}$ ). Under physiological conditions, $\mathrm{Fe}$ is transported in the plasma bound to transferrin, which is taken up by the hepatocytes by binding to the transferrin receptor (TfR). The mRNA expression of TfR was only upregulated in the -Se Nrf2 KO mice (Figure 4G) together with expression levels of the Fe transporter DMT1 (Figure 4H), which is consistent with higher Fe levels in the liver. In the plasma, ferrous Fe is immediately oxidized to ferric Fe by $\mathrm{Cu}$-dependent $\mathrm{Cp}$, and then bound to transferrin. Also, $\mathrm{Cp}$ was upregulated in the -Se Nrf2 KO group (Figure $4 \mathrm{I}) . \mathrm{Cp}$ is an acute phase protein, which is known to be sensitive towards inflammation. However, no increase in hepatic inflammatory cells has been detected in Nrf2 KO mice previously [37]. Intracellularly, Fe is efficiently bound to ferritin. The subunit ferritin H (FTH) is regulated by Nrf2 [16]. Herein, mRNA of FTH was only reduced under + Se and ++ Se conditions (Figure 4J). However, ferritin $\mathrm{H}$ protein levels were almost undetectable also in -Se Nrf2 KO mice (Figure $4 \mathrm{~K}, \mathrm{~L}$ ). In addition, ferritin $\mathrm{H}$ protein was upregulated under -Se conditions in WT mice in comparison to +Se WT mice. 



G

$\mathrm{H}$

I
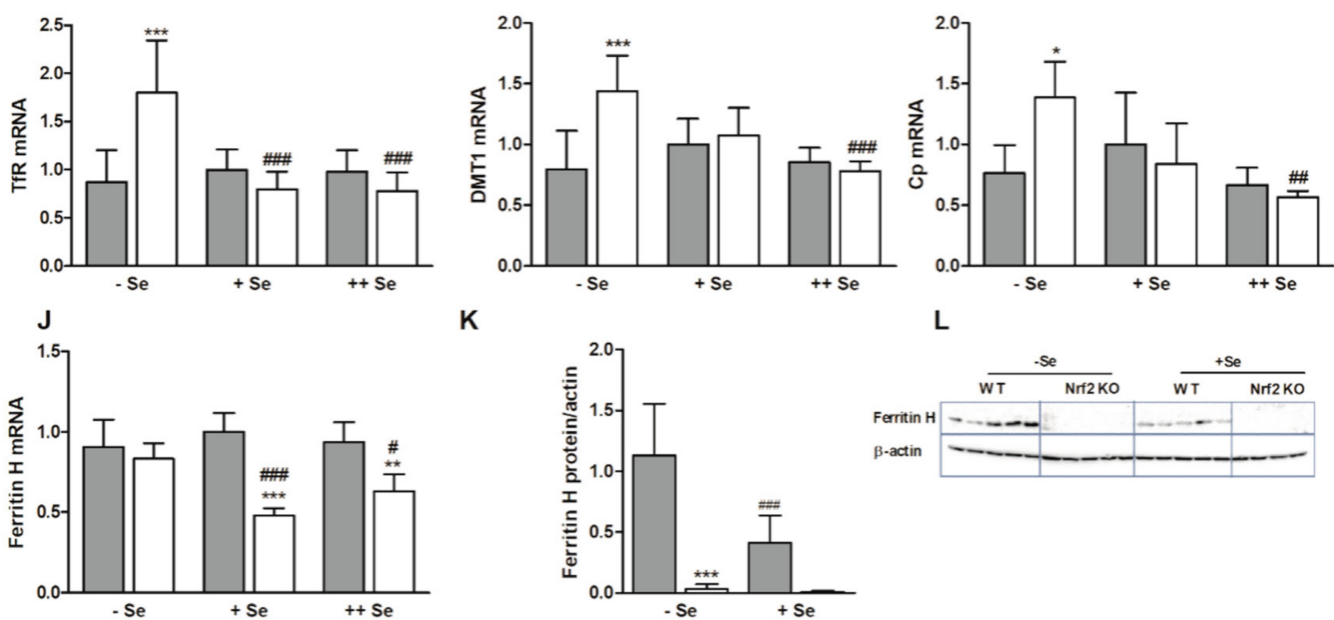

L

Figure 4. Biomarkers of the Fe status. Fe (A), ferritin (B), and transferrin (C) concentrations in the plasma of male Nrf2 KO and WT mice fed diets with defined Se contents (-Se: 0.03 ppm; +Se: 0.15 ppm; ++Se: $0.6 \mathrm{ppm})$. Additionally, Fe concentration in the liver (D) as well as mRNA and protein expression of Fe-related genes/proteins in the liver were determined by qPCR or western blot, respectively (E,G-L). Ferroportin mRNA was measured in the duodenum (F). The TE profile was analyzed using ICP-MS/MS (A,D). Further Fe plasma parameters were detected by ELISA (B,C). Bars represent means + SD $(n=4-5)$. ${ }^{*} p<0.05$; ${ }^{* *} p<0.01$; ${ }^{* * *} p<0.001$ vs. WT and ${ }^{\#} p<0.05$; ${ }^{\# \#} p<0.01$; \#\# $p<0.001$ vs. -Se (two-way ANOVA with Bonferroni's post-test).

As in the previous experiment (Figure 1), there was no effect of Nrf2 on hepatic or plasma $\mathrm{Cu}$ levels under $++\mathrm{Se}$ conditions, but under $-\mathrm{Se}$ and $+\mathrm{Se}$ conditions hepatic $\mathrm{Cu}$ levels were reduced (Figure 5B) while plasma values were increased in the -Se Nrf2 KO group (Figure 5A). The latter obviously resulted from lower $\mathrm{Cu}$ levels of $-\mathrm{Se}$ WT mice in comparison to +Se WT mice. Higher expression levels of Atp7b (Figure 5G) might be the reason for lower Cu levels in -Se Nrf2 KO mice, while at the same time, higher $\mathrm{Cu}$ plasma levels could be explained by more efficient binding of $\mathrm{Cu}$ to $\mathrm{Cp}$ (Figure 4I) being excreted from hepatocytes. The $\mathrm{Cu}$ transporter 1 (Ctr1) is important for $\mathrm{Cu}$ as well as $\mathrm{Zn}$ absorption in the intestine; however, hepatocytes also express $\mathrm{Ctr} 1$ in relevant amounts to take up $\mathrm{Cu}$ from the circulation. Ctr1 protein expression was completely unaffected by the Nrf2 genotype or Se supply (Figure 5C). 
A



D



G

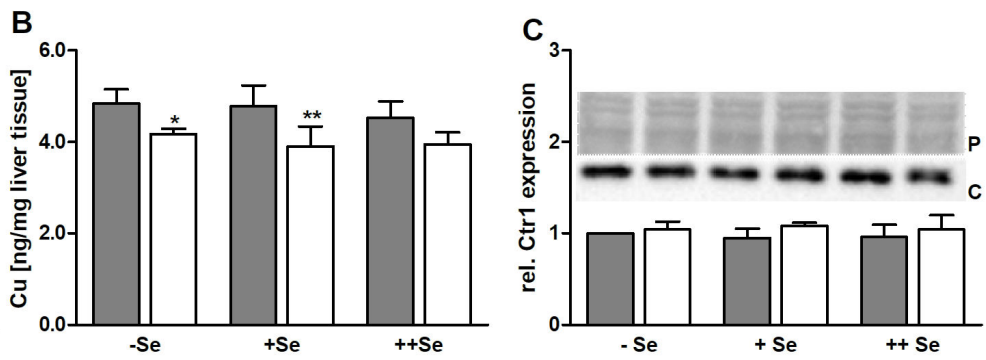

E



F

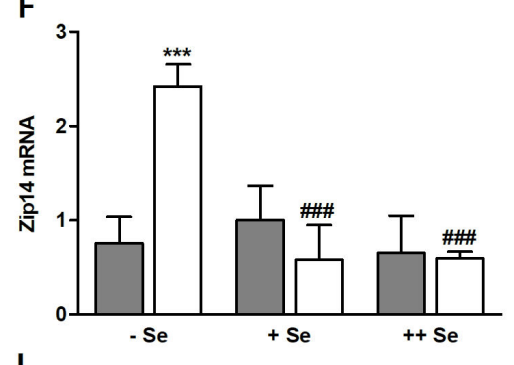

I
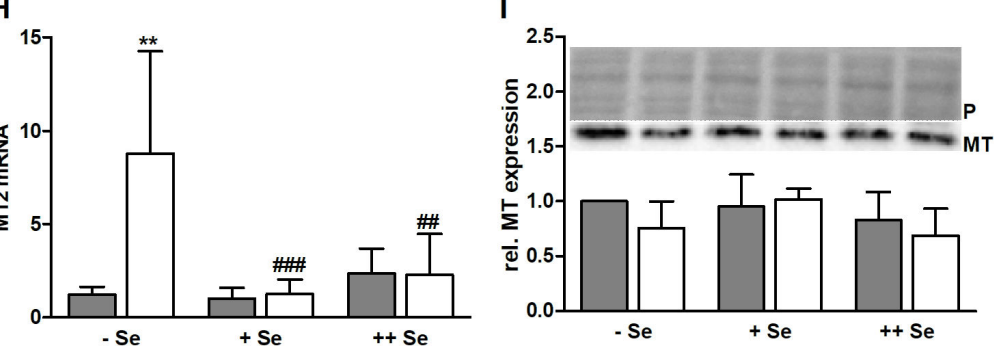

Figure 5. Biomarkers of the $\mathrm{Cu}$ and $\mathrm{Zn}$ status. $\mathrm{Cu}$ and $\mathrm{Zn}$ concentrations in the plasma $(\mathbf{A}, \mathrm{C})$ and liver (B,D) of male Nrf2 KO and WT mice fed diets with defined Se contents (-Se: 0.03 ppm; +Se: 0.15 ppm; ++ Se: $0.6 \mathrm{ppm})$, analyzed by ICP-MS/MS. Additionally, mRNA (F-H) and protein expression (C, I-J) of $\mathrm{Cu}$ - and $\mathrm{Zn}$-related genes/proteins in the liver of these animals were determined. Western blots were normalized to the Ponceau staining (P). Bars represent means + SD $(n=4-5) .{ }^{*} p<0.05 ;{ }^{* *} p<0.01$; *** $p<0.001$ vs. WT and ${ }^{\#} p<0.05$; ${ }^{\# \#} p<0.01$; \#\#\# $p<0.001$ vs. -Se (two-way ANOVA with Bonferroni's post-test). $\mathrm{C}=\mathrm{Ctr1}$.

As seen before, hepatic Zn levels were neither affected by Nrf2 nor by Se status (Figure 5E). However, plasma concentrations were substantially reduced in Nrf2 KO mice under -Se conditions (Figure 5D). There was a concentration-dependent decrease of plasma $\mathrm{Zn}$ values with an increasing Se supply. In contrast to other members of the Zip family, Zip14 transports not only Zn but also Fe. Herein, intracellular Fe concentrations were increased in -Se Nrf2 KO mice, and at the same time, Zip14 mRNA levels were upregulated under these conditions (Figure 5F). Also, MT2 shows a very similar mRNA expression pattern (Figure 5H) to Zip14. It was highly upregulated in -Se Nrf2 KO livers. However, western blots with an antibody against all MT isoforms could not confirm the effect observed for MT2 mRNA expression (Figure 5I). As a potential mechanistic link between regulated genes and the Nrf2 and Se status, MTF1 expression was analyzed in the liver. MTF1 was significantly downregulated in ++ Se Nrf2 KO mice (Figure 5J), but MTF1 levels declined with reduction of the Se status and thus the Nrf2 KO effect was lost under +Se and -Se conditions. 


\section{Discussion}

It is well established that the transcription factor Nrf2 is an important mediator of Fe homeostasis [8]. In this study, we addressed the question of whether other trace elements, such as $\mathrm{Se}, \mathrm{Zn}$, and $\mathrm{Cu}$, are modulated by Nrf2 as well. A reduction of Nrf2 levels and responsiveness is a relevant health condition that physiologically takes place during aging [38]. Thus, the question arises whether age-specific changes in TE profiles [39] might be related to Nrf2. Recently, it has been examined that Nrf2 activity levels strongly differ in the liver of male and female mice [40]. Also, herein, we were able to show that basal NQO1 mRNA expression in WT livers is much higher in female than in male mice (Figure S1C). Thus, sex differences of TEs could be attributed to higher Nrf2 activity as well. All three TEs, Fe, Cu, and $\mathrm{Zn}$, were indeed higher in the plasma of female than in male mice (Table 4), but the underlying mechanisms are unclear so far. Also, MT2 mRNA levels were substantially higher in female livers but at the same time independent of the Nrf2 status (Figure S1E).

Table 4. Effects of Nrf2 genotype, sex, and a suboptimal Se status on homeostasis of Fe, Zn, and Cu.

\begin{tabular}{cccc}
\hline TE & $\begin{array}{c}\text { Nrf2 Genotype } \\
\text { (KO vs. WT) }\end{array}$ & $\begin{array}{c}\text { Sex in WT Mice } \\
\text { (Female vs. Male) }\end{array}$ & $\begin{array}{c}\text { Se Effect in WT Mice } \\
\text { (-Se vs. }+ \text { ++Se) }\end{array}$ \\
\hline $\mathrm{Cu}$ & $\begin{array}{c}\text { intracellular } \mathrm{Cu} \rightarrow \\
\text { plasma Cu }(\downarrow)\end{array}$ & plasma Cu $\uparrow$ & plasma $\mathrm{Cu} \rightarrow$ \\
\hline $\mathrm{Fe}$ & $\begin{array}{c}\text { intracellular Fe } \uparrow \\
\text { plasma Fe biomarkers } \rightarrow\end{array}$ & liver and plasma Fe $\uparrow$ & only hepatic ferritin $\mathrm{H} \uparrow$ \\
\hline $\mathrm{Se}$ & $\begin{array}{c}\text { intracellular Se } \downarrow \\
\text { plasma Se } \rightarrow\end{array}$ & liver Se $\uparrow$ & $\downarrow$ as expected \\
\hline $\mathrm{Zn}$ & $\begin{array}{c}\text { intestinal and plasma } \mathrm{Zn} \downarrow \\
\text { liver } \mathrm{Zn} \rightarrow\end{array}$ & plasma $\mathrm{Zn} \uparrow$ & plasma $\mathrm{Zn} \downarrow$ \\
\hline
\end{tabular}

We observed an increase in Fe tissue levels upon loss of Nrf2 (Figure 1A,B and Figure 4D). Vice versa, Nrf2 protects the murine liver against dietary Fe overload by enhancing Fe release [6]. Combining a genetic mouse model for hereditary hemochromatosis with an Nrf2 KO results in hepatic fibrosis, which could otherwise be prohibited by upregulation of Nrf2 target genes [41]. Furthermore, under conditions of nutritional steatohepatitis, Nrf2 inhibits hepatic Fe accumulation and thereby counteracts oxidative stress [42]. Recently, it has been shown that Fe-induced Nrf2 activation enhances bone morphogenetic protein 6 (Bmp6) signaling, which upregulates hepcidin expression to fine-tune Fe homeostasis [36]. One of the first observations indicating a change in Fe homeostasis in Nrf2 KO mice was the finding that Nrf2 KO mice have abnormally white teeth in comparison to WT mice due to defective Fe utilization during tooth development [43]. Higher Fe tissue levels can be attributed to the Fe exporter Fpn1, which was downregulated in male Nrf2 KO mice (Figure 4F and Figure S1D), and to the hepatic Fe importers, TfR and DMT1 [44], which were upregulated in -Se Nrf2 KO mice (Figure 4G,H). Also, Zip14 was strongly induced in -Se Nrf2 KO mice (Figure 5F). Zip14 was originally described as a $\mathrm{Zn}$ importer with the highest expression in the jejunum and liver, but it is now established that it transports further TEs, such as Fe [45]. Under conditions of Fe depletion, Zip14 membrane localization is impaired based on post-translational modifications [46]. Under physiological conditions, Fe is mainly transported bound to transferrin. Thus, TfR appears to be of major relevance for Fe uptake into the liver. To get an idea of the putative crosstalk between several TEs, we included DMT1 and Zip14, as those not only transport Fe but also additional TEs. Usually, the intracellular free labile Fe pool is tightly regulated. One of the most important regulating proteins is ferritin, which is able to bind up to 4,500 Fe atoms in its core [47]. The amount of intracellular ferritin $\mathrm{H}$ was strongly reduced in Nrf2 KO mice (Figure 4J-L), especially on the protein level, indicating that the labile free Fe pool is substantially increased under those conditions. Ferritin can be secreted from both hepatocytes and Kupffer cells to contribute to plasma ferritin levels in addition to the relevant amounts secreted by macrophages [48]. Surprisingly, plasma ferritin levels stayed unaffected by the Nrf2 genotype 
(Figure 4B and Figure S1A). This might be explained by the fact that plasma ferritin mostly consists of the ferritin L subunit and not $\mathrm{H}$ [49], even though ferritin L has been identified as an Nrf2 target gene as well [50]. Based on the observed substantial downregulation of ferritin $\mathrm{H}$, effects of Fe on the liver are supposed to be stronger than detected. Eventually, Fe availability to the systemic circulation is also reduced in $\mathrm{Nrf} 2 \mathrm{KO}$ mice, counteracting the loss of Nrf2-mediated limitation of the intracellular free $\mathrm{Fe}$ pool. Indeed, intestinal Fpn1 expression was reduced in Nrf2 KO mice (Figure 4F), indicating that absorbed Fe might be retained there and released back into the intestinal lumen when enterocytes go into apoptosis. In line with this, Fe plasma levels were reduced in Nrf2 $\mathrm{KO}$ mice but only in females (Figure 1F).

In parallel to Fe, intracellular levels of Se and Zn were affected by loss of Nrf2 as well. In this case, both were reduced. Also, plasma $\mathrm{Cu}$ levels were slightly reduced in $\mathrm{Nrf2} \mathrm{KO}$ mice (overview in Table 4). Overall, these effects were rather small. For Se, the small reduction in liver Se levels could not be confirmed by analyzing selenoproteins, which respond very sensitively towards changes in the Se status. This was the case for total GPX activity. Only Selenow mRNA expression, which might be a useful additional biomarker for the Se status [51], was slightly reduced in Nrf2 KO mice under +Se conditions (Figure 2E). Thus, Nrf2 does not appear to be a major regulator of the Se status.

Comparable to Zip14, mRNA levels of Atp7b, the essential ATPase for Cu export into the bile [10], were upregulated under-Se Nrf2 KO conditions (Figure 5F,G). Additionally, DMT1 (Figure 4F) and MT2 revealed a similar expression pattern (Figure $5 \mathrm{H}$ ), which could not be confirmed on the protein level when using an antibody capable of detecting all MT isoforms (Figure 5I). MT isoforms are cysteine-rich proteins that efficiently bind $\mathrm{Cu}$ and $\mathrm{Zn}$ to reduce the amount of both TEs in their free form [9]. Feeding of rats with the Nrf2 activator sulforaphane resulted in a robust induction of genes encoding for MT-1/2 and MT1a [52]. The MT1 promoter contains an ARE that is activated by Nrf1 and Nrf2, but in the latter case, not to the same extent. In Nrf1 KO mice, basal levels of both MT1 and MT2 genes were reduced [25]. Herein, we did not detect any downregulation of MT2 mRNA upon loss of Nrf2. As several genes (MT2, Atp 7b, Zip14, Cp, TfR, and Dmt1) showed a comparable expression pattern, being induced specifically under -Se Nrf2 $\mathrm{KO}$ conditions, the question arose if there is a common regulator. One possibility would be MTF1, which regulates MT expression in response to $\mathrm{Zn}$ or $\mathrm{Cu}$ [53]. Recently, it has been shown that the disruption of an MTF1 binding site by a homozygous variant in the promoter of Atp7b likely causes Wilson disease [24]. In addition, the induction of Fpn1 transcription by MTF1 has been shown [54]. However, there was no detectable MTF1 activation in -Se Nrf2 KO livers. In contrast, MTF1 was upregulated in a concentration-dependent manner as a response to Se. Only under ++Se conditions, an Nrf2 genotype effect was detectable, showing lower MTF1 levels upon loss of Nrf2. Thus, MTF1 expression does not provide an obvious explanation for the observed mRNA expression pattern of some MTF1 target genes.

Besides DMT1, Ctr1 is the main universal $\mathrm{Cu}$ importer in mammalian cells. A KO of $\mathrm{Ctr} 1$ in the intestine resulted in peripheral $\mathrm{Cu}$ hypoaccumulation. In parallel, hepatic Fe levels were upregulated [55]. Expression of Ctr1 was unaffected by the Nrf2 genotype and hepatic Se levels (Figure 5C). Furthermore, an Se-dependent reduction of plasma Zn concentration was observed (Figure 5D). An intestine-specific Ctr1 KO did not modulate the systemic Zn status [55], while liver-specific $\mathrm{Ctr1} \mathrm{KO}$ mice showed a transient increase in hepatic Zn levels but not in serum [56]. Taken together, homeostasis of $\mathrm{Zn}$ and $\mathrm{Cu}$ also appears to be regulated rather independently of Nrf2. However, it is possible that there are short-term effects of Nrf2 on TE homeostasis, which might be undetectable in constitutive $\mathrm{KO}$ mice because of putative adaptation processes in response to a loss of Nrf2 over time.

We and others have shown previously that a suboptimal selenium supply results in Nrf2 activation predominantly in the liver and intestine of mice [17,57]. This can be attributed mainly to low levels of the selenoproteins TXNRD1 and GPX4, as single KOs of one of these two selenoproteins also activate Nrf2 [28,58-60]. Patients with Kaschin-Beck disease, a disease diagnosed under conditions of Se deficiency, have been characterized by higher expression of Nrf2 and its target gene Hmox 1 in whole 
blood samples as compared to healthy controls, indicating potential Nrf2 activation in humans under Se deficient conditions [61]. However, in this case, we could not confirm previous results and observed no Nrf2 activation indicated by NQO1 and GST activity in the liver (Figure 3) or intestine (Figure S2) of mice fed an -Se diet, even though the levels of TXNRD and GPX activity were in a comparable range to previous experiments $[17,26]$. Only the $\mathrm{Nrf} 2$ target gene ferritin $H$ was clearly upregulated in -Se WT livers and was almost lost in Nrf2 KO mice (Figure 4K,L). This phenomenon has also been described in another recent study analyzing the response to lifelong dietary Se interventions in mice. Additionally, in this study, no effect of an Se-deficient diet could be observed on hepatic Nrf2 response genes considering whole transcriptome analyses [62]. Another study found that Se deficiency affected the expression of neither Hmox1 nor NQO1 [63]. In those two studies, and similar to our study, Se deficiency decreased the expression of important selenoproteins but did not activate Nrf2. Thus, it has been suggested that a low Se status interacts with another dietary or environmental component to regulate the Nrf2 response but is not sufficient by itself [62].

Therefore, the initial aim of studying the crosstalk between Nrf2 and selenium status in modulating three other TEs is difficult to address under the present conditions. Herein, it is relatively clear that Se effects observed on $\mathrm{Zn}$ appear to be regulated independently of Nrf2. However, when only considering WT mice, we could still draw conclusions towards the role of the Se status on TE status of Zn, Fe, and Cu. Most strikingly, Zn plasma levels were higher in mice with low Se status and vice versa (Figure 5D). In comparison to that, $\mathrm{Cu}$ and Fe were rather unaffected by Se. At the same time, hepatic $\mathrm{Zn}$ levels were unaffected by the Se status, indicating that $\mathrm{Zn}$ appears to be taken up by other tissues besides the liver when Se levels are rising. As MTF1 shows the complete opposite effect than plasma Zn levels and also as most of the MTF1 target genes, it might be an attempt to compensate for the low Se status. Any underlying mechanisms, however, are unclear so far.

\section{Conclusions}

Overall, only Fe was substantially regulated in response to Nrf2 while the impact of Nrf2 on homeostasis of $\mathrm{Se}, \mathrm{Cu}$, and $\mathrm{Zn}$ appeared to be rather marginal. Nevertheless, crosstalk between Se and MTF1 is a promising idea that needs to be followed up in the future and might provide an explanation for the observed counter regulation of plasma Se and $\mathrm{Zn}$ levels.

The mammalian ionome has been evaluated in 26 species and across several tissues [64]. In this study, $\mathrm{Zn}$ levels in the liver and kidney were positively correlated with maximum lifespan while hepatic Se was negatively correlated with longevity, albeit in a relatively weak manner. The Nrf2 responsiveness is reduced during aging, which provides a putative explanation for changes in TE profiles in the elderly and for TE effects on longevity. We have recently shown in a reinvited sub-cohort of the EPIC Potsdam study that $\mathrm{Cu}$ and Fe serum levels increased over time, while $\mathrm{Zn}$ and Se levels showed an age-dependent decline [39]. This is supposed to be associated with a reduction in Nrf2 activity for which, herein, Nrf2 KO mice were used as a model. Also, in Nrf2 KO mice, Se and Zn levels were reduced; however, there was no upregulation but rather a slight downregulation of the systemic $\mathrm{Cu}$ status (Table 4). Systemic Fe levels increased in Nrf2 KO mice but that was shown herein for intracellular amounts and not for plasma biomarkers as done in the EPIC study. Thus, it needs to be further clarified how age-dependent changes in the TE status are modulated on the molecular level.

Supplementary Materials: The following are available online at http://www.mdpi.com/2072-6643/11/9/2112/s1, Figure S1: Ferritin and transferrin concentrations in the plasma and mRNA expression in the livers of male and female Nrf2 KO and WT mice fed a standard chow diet. Figure S2: NQO1 mRNA (A) and activity (B) in the duodenum of male Nrf2 KO and WT mice fed diets with defined Se content (-Se: 0.03 ppm; +Se: 0.15 ppm; ++ Se: $0.6 \mathrm{ppm})$.

Author Contributions: A.P.K. and T.S. were responsible for the conceptualization of the study, supervision, and funding acquisition; M.S., K.L. and J.F.K. established the methodology, performed the analyses and prepared the original draft.

Funding: This research was funded by German Research Foundation (DFG), FOR 2558. 
Acknowledgments: The authors highly acknowledge the support of Franziska Hiller in organizing the animal experiment and excellent technical support by Stefanie Deubel, Gabriele Pohl, and Sören Meyer. In addition, we thank Masayuki Yamamoto for providing the Nrf2 KO mice.

Conflicts of Interest: The authors declare no conflict of interest.

\section{References}

1. Brigelius-Flohé, R.; Flohé, L. Basic principles and emerging concepts in the redox control of transcription factors. Antioxid. Redox. Signal. 2011, 15, 2335-2381. [CrossRef]

2. Tebay, L.E.; Robertson, H.; Durant, S.T.; Vitale, S.R.; Penning, T.M.; Dinkova-Kostova, A.T.; Hayes, J.D. Mechanisms of activation of the transcription factor Nrf2 by redox stressors, nutrient cues, and energy status and the pathways through which it attenuates degenerative disease. Free. Radic. Biol. Med. 2015, 88, 108-146. [CrossRef]

3. Hayes, J.D.; Dinkova-Kostova, A.T. The Nrf2 regulatory network provides an interface between redox and intermediary metabolism. Trends. Biochem. Sci. 2014, 39, 199-218. [CrossRef]

4. McMahon, M.; Swift, S.R.; Hayes, J.D. Zinc-binding triggers a conformational-switch in the cullin-3 substrate adaptor protein KEAP1 that controls transcription factor NRF2. Toxicol. Appl. Pharmacol. 2018, 360, 45-57. [CrossRef]

5. Moon, M.S.; McDevitt, E.I.; Zhu, J.; Stanley, B.; Krzeminski, J.; Amin, S.; Aliaga, C.; Miller, T.G.; Isom, H.C. Elevated hepatic iron activates NF-E2-related factor 2-regulated pathway in a dietary iron overload mouse model. Toxicol. Sci. 2012, 129, 74-85. [CrossRef]

6. Silva-Gomes, S.; Santos, A.G.; Caldas, C.; Silva, C.M.; Neves, J.V.; Lopes, J.; Carneiro, F.; Rodrigues, P.N.; Duarte, T.L. Transcription factor NRF2 protects mice against dietary iron-induced liver injury by preventing hepatocytic cell death. J. Hepatol. 2014, 60, 354-361. [CrossRef]

7. Harada, N.; Kanayama, M.; Maruyama, A.; Yoshida, A.; Tazumi, K.; Hosoya, T.; Mimura, J.; Toki, T.; Maher, J.M.; Yamamoto, M.; et al. Nrf2 regulates ferroportin 1-mediated iron efflux and counteracts lipopolysaccharide-induced ferroportin 1 mRNA suppression in macrophages. Arch. Biochem. Biophys. 2011, 508, 101-109. [CrossRef]

8. Kerins, M.J.; Ooi, A. The Roles of NRF2 in Modulating Cellular Iron Homeostasis. Antioxid. Redox Signal. 2018, 29, 1756-1773. [CrossRef]

9. Davis, S.R.; Cousins, R.J. Metallothionein expression in animals: A physiological perspective on function. J. Nutr. 2000, 130, 1085-1088. [CrossRef]

10. Polishchuk, E.V.; Concilli, M.; Iacobacci, S.; Chesi, G.; Pastore, N.; Piccolo, P.; Paladino, S.; Baldantoni, D.; van, I.S.C.; Chan, J.; et al. Wilson disease protein ATP7B utilizes lysosomal exocytosis to maintain copper homeostasis. Dev. Cell 2014, 29, 686-700. [CrossRef]

11. Lutsenko, S. Human copper homeostasis: A network of interconnected pathways. Curr. Opin. Chem. Biol. 2010, 14, 211-217. [CrossRef]

12. Mocchegiani, E.; Costarelli, L.; Giacconi, R.; Malavolta, M.; Basso, A.; Piacenza, F.; Ostan, R.; Cevenini, E.; Gonos, E.S.; Monti, D. Micronutrient-gene interactions related to inflammatory/immune response and antioxidant activity in ageing and inflammation. A systematic review. Mech. Ageing Dev. 2014, 136-137, 29-49. [CrossRef]

13. Song, M.O.; Mattie, M.D.; Lee, C.H.; Freedman, J.H. The role of Nrf1 and Nrf2 in the regulation of copper-responsive transcription. Exp. Cell. Res. 2014, 322, 39-50. [CrossRef]

14. Cui, Z.; Zhong, Z.; Yang, Y.; Wang, B.; Sun, Y.; Sun, Q.; Yang, G.Y.; Bian, L. Ferrous Iron Induces Nrf2 Expression in Mouse Brain Astrocytes to Prevent Neurotoxicity. J. Biochem. Mol. Toxicol. 2016, 30, $396-403$. [CrossRef]

15. Alam, J.; Cook, J.L. Transcriptional regulation of the heme oxygenase-1 gene via the stress response element pathway. Curr. Pharm. Des. 2003, 9, 2499-2511. [CrossRef]

16. Pietsch, E.C.; Chan, J.Y.; Torti, F.M.; Torti, S.V. Nrf2 mediates the induction of ferritin H in response to xenobiotics and cancer chemopreventive dithiolethiones. J. Biol. Chem. 2003, 278, 2361-2369. [CrossRef]

17. Müller, M.; Banning, A.; Brigelius-Flohé, R.; Kipp, A. Nrf2 target genes are induced under marginal selenium-deficiency. Genes. Nutr. 2010, 5, 297-307. [CrossRef] 
18. Zhang, J.; Wang, H.; Peng, D.; Taylor, E.W. Further insight into the impact of sodium selenite on selenoenzymes: High-dose selenite enhances hepatic thioredoxin reductase 1 activity as a consequence of liver injury. Toxicol. Lett. 2008, 176, 223-229. [CrossRef]

19. Banning, A.; Deubel, S.; Kluth, D.; Zhou, Z.; Brigelius-Flohé, R. The GI-GPx gene is a target for Nrf2. Mol. Cell. Biol. 2005, 25, 4914-4923. [CrossRef]

20. Sakurai, A.; Nishimoto, M.; Himeno, S.; Imura, N.; Tsujimoto, M.; Kunimoto, M.; Hara, S. Transcriptional regulation of thioredoxin reductase 1 expression by cadmium in vascular endothelial cells: Role of NF-E2-related factor-2. J. Cell. Physiol. 2005, 203, 529-537. [CrossRef]

21. Li, B.; Cui, W.; Tan, Y.; Luo, P.; Chen, Q.; Zhang, C.; Qu, W.; Miao, L.; Cai, L. Zinc is essential for the transcription function of Nrf2 in human renal tubule cells in vitro and mouse kidney in vivo under the diabetic condition. J. Cell. Mol. Med. 2014, 18, 895-906. [CrossRef]

22. Wakabayashi, N.; Slocum, S.L.; Skoko, J.J.; Shin, S.; Kensler, T.W. When NRF2 talks, who's listening? Antioxid. Redox. Signal. 2010, 13, 1649-1663. [CrossRef]

23. Gunther, V.; Lindert, U.; Schaffner, W. The taste of heavy metals: Gene regulation by MTF-1. Biochim. Biophys. Acta 2012, 1823, 1416-1425. [CrossRef]

24. Chen, H.I.; Jagadeesh, K.A.; Birgmeier, J.; Wenger, A.M.; Guturu, H.; Schelley, S.; Bernstein, J.A.; Bejerano, G. An MTF1 binding site disrupted by a homozygous variant in the promoter of ATP7B likely causes Wilson Disease. Eur. J. Hum. Genet. 2018, 26, 1810-1818. [CrossRef]

25. Ohtsuji, M.; Katsuoka, F.; Kobayashi, A.; Aburatani, H.; Hayes, J.D.; Yamamoto, M. Nrf1 and Nrf2 play distinct roles in activation of antioxidant response element-dependent genes. J. Biol. Chem. 2008, 283, 33554-33562. [CrossRef]

26. Lennicke, C.; Rahn, J.; Kipp, A.P.; Dojcinovic, B.P.; Müller, A.S.; Wessjohann, L.A.; Lichtenfels, R.; Seliger, B. Individual effects of different selenocompounds on the hepatic proteome and energy metabolism of mice. Biochim. Biophys. Acta. 2017, 1861, 3323-3334. [CrossRef]

27. Rayman, M.P. Selenium and human health. Lancet 2012, 379, 1256-1268. [CrossRef]

28. Cebula, M.; Schmidt, E.E.; Arnér, E.S. TrxR1 as a potent regulator of the Nrf2-Keap1 response system. Antioxid. Redox Signal. 2015, 23, 823-853. [CrossRef]

29. Itoh, K.; Chiba, T.; Takahashi, S.; Ishii, T.; Igarashi, K.; Katoh, Y.; Oyake, T.; Hayashi, N.; Satoh, K.; Hatayama, I.; et al. An Nrf2/small Maf heterodimer mediates the induction of phase II detoxifying enzyme genes through antioxidant response elements. Biochem. Biophys. Res. Commun. 1997, 236, 313-322. [CrossRef]

30. Ritskes-Hoitinga, M. Nutrition of the laboratory mouse. In The Laboratory Mouse; Academic Press, Elsevier: London, UK, 2012; pp. 567-596.

31. Marschall, T.A.; Kroepfl, N.; Jensen, K.B.; Bornhorst, J.; Meermann, B.; Kuehnelt, D.; Schwerdtle, T. Tracing cytotoxic effects of small organic Se species in human liver cells back to total cellular Se and Se metabolites. Metallomics 2017, 9, 268-277. [CrossRef]

32. Kopp, J.F.; Müller, S.M.; Pohl, G.; Lossow, K.; Kipp, A.P.; Schwerdtle, T. A quick and simple method for the determination of six trace elements in mammalian serum samples using ICP-MS/MS. J. Trace Elem. Med. Biol. 2019, 54, 221-225. [CrossRef]

33. Krehl, S.; Loewinger, M.; Florian, S.; Kipp, A.P.; Banning, A.; Wessjohann, L.A.; Brauer, M.N.; Iori, R.; Esworthy, R.S.; Chu, F.F.; et al. Glutathione peroxidase-2 and selenium decreased inflammation and tumors in a mouse model of inflammation-associated carcinogenesis whereas sulforaphane effects differed with selenium supply. Carcinogenesis 2012, 33, 620-628. [CrossRef]

34. Florian, S.; Krehl, S.; Loewinger, M.; Kipp, A.; Banning, A.; Esworthy, S.; Chu, F.F.; Brigelius-Flohé, R. Loss of GPx2 increases apoptosis, mitosis and GPx1 expression in the intestine of mice. Free. Radic. Biol. Med. 2010, 49, 1694-1702. [CrossRef]

35. Habig, W.H.; Pabst, M.J.; Jakoby, W.B. Glutathione S-transferases. The first enzymatic step in mercapturic acid formation. J. Biol. Chem. 1974, 249, 7130-7139.

36. Lim, P.J.; Duarte, T.L.; Arezes, J.; Garcia-Santos, D.; Hamdi, A.; Pasricha, S.R.; Armitage, A.E.; Mehta, H.; Wideman, S.; Santos, A.G.; et al. Nrf2 controls iron homeostasis in haemochromatosis and thalassaemia via Bmp6 and hepcidin. Nat. Metab. 2019, 1, 519-531. [CrossRef]

37. Köhler, U.A.; Böhm, F.; Rolfs, F.; Egger, M.; Hornemann, T.; Pasparakis, M.; Weber, A.; Werner, S. NF-kappaB/RelA and Nrf2 cooperate to maintain hepatocyte integrity and to prevent development of hepatocellular adenoma. J. Hepatol. 2016, 64, 94-102. [CrossRef] 
38. Huang, D.D.; Fan, S.D.; Chen, X.Y.; Yan, X.L.; Zhang, X.Z.; Ma, B.W.; Yu, D.Y.; Xiao, W.Y.; Zhuang, C.L.; Yu, Z. $\mathrm{Nrf} 2$ deficiency exacerbates frailty and sarcopenia by impairing skeletal muscle mitochondrial biogenesis and dynamics in an age-dependent manner. Exp. Gerontol. 2019, 119, 61-73. [CrossRef]

39. Baudry, J.; Kopp, J.F.; Boeing, H.; Kipp, A.P.; Schwerdtle, T.; Schulze, M.B. Changes of trace element status during aging: Results of the EPIC-Potsdam cohort study. Eur. J. Nutr. 2019. submitted.

40. Rooney, J.; Oshida, K.; Vasani, N.; Vallanat, B.; Ryan, N.; Chorley, B.N.; Wang, X.; Bell, D.A.; Wu, K.C.; Aleksunes, L.M.; et al. Activation of Nrf2 in the liver is associated with stress resistance mediated by suppression of the growth hormone-regulated STAT5b transcription factor. PLOS ONE 2018, 13, e0200004. [CrossRef]

41. Duarte, T.L.; Caldas, C.; Santos, A.G.; Silva-Gomes, S.; Santos-Goncalves, A.; Martins, M.J.; Porto, G.; Lopes, J.M. Genetic disruption of NRF2 promotes the development of necroinflammation and liver fibrosis in a mouse model of HFE-hereditary hemochromatosis. Redox Biol. 2017, 11, 157-169. [CrossRef]

42. Okada, K.; Warabi, E.; Sugimoto, H.; Horie, M.; Tokushige, K.; Ueda, T.; Harada, N.; Taguchi, K.; Hashimoto, E.; Itoh, K.; et al. Nrf2 inhibits hepatic iron accumulation and counteracts oxidative stress-induced liver injury in nutritional steatohepatitis. J. Gastroenterol. 2012, 47, 924-935. [CrossRef]

43. Yanagawa, T.; Itoh, K.; Uwayama, J.; Shibata, Y.; Yamaguchi, A.; Sano, T.; Ishii, T.; Yoshida, H.; Yamamoto, M. Nrf2 deficiency causes tooth decolourization due to iron transport disorder in enamel organ. Genes Cells 2004, 9, 641-651. [CrossRef]

44. Shindo, M.; Torimoto, Y.; Saito, H.; Motomura, W.; Ikuta, K.; Sato, K.; Fujimoto, Y.; Kohgo, Y. Functional role of DMT1 in transferrin-independent iron uptake by human hepatocyte and hepatocellular carcinoma cell, HLF. Hepatol. Res. 2006, 35, 152-162. [CrossRef]

45. Liuzzi, J.P.; Aydemir, F.; Nam, H.; Knutson, M.D.; Cousins, R.J. Zip14 (Slc39a14) mediates non-transferrin-bound iron uptake into cells. Proc. Natl. Acad. Sci. USA 2006, 103, 13612-13617. [CrossRef]

46. Aydemir, T.B.; Cousins, R.J. The Multiple Faces of the Metal Transporter ZIP14 (SLC39A14). J. Nutr. 2018, 148, 174-184. [CrossRef]

47. Macara, I.G.; Hoy, T.G.; Harrison, P.M. The formation of ferritin from apoferritin. Kinetics and mechanism of iron uptake. Biochem. J. 1972, 126, 151-162. [CrossRef]

48. Wang, W.; Knovich, M.A.; Coffman, L.G.; Torti, F.M.; Torti, S.V. Serum ferritin: Past, present and future. Biochim. Biophys. Acta. 2010, 1800, 760-769. [CrossRef]

49. Santambrogio, P.; Cozzi, A.; Levi, S.; Arosio, P. Human serum ferritin G-peptide is recognized by anti-L ferritin subunit antibodies and concanavalin-A. Br. J. Haematol. 1987, 65, 235-237. [CrossRef]

50. Kuosmanen, S.M.; Viitala, S.; Laitinen, T.; Perakyla, M.; Polonen, P.; Kansanen, E.; Leinonen, H.; Raju, S.; Wienecke-Baldacchino, A.; Narvanen, A.; et al. The Effects of Sequence Variation on Genome-wide NRF2 Binding-New Target Genes and Regulatory SNPs. Nucleic Acids Res. 2016, 44, 1760-1775. [CrossRef]

51. Kipp, A.P.; Frombach, J.; Deubel, S.; Brigelius-Flohé, R. Selenoprotein W as biomarker for the efficacy of selenium compounds to act as source for selenoprotein biosynthesis. Methods Enzymol. 2013, 527, 87-112.

52. Hu, R.; Hebbar, V.; Kim, B.R.; Chen, C.; Winnik, B.; Buckley, B.; Soteropoulos, P.; Tolias, P.; Hart, R.P.; Kong, A.N. In vivo pharmacokinetics and regulation of gene expression profiles by isothiocyanate sulforaphane in the rat. J. Pharmacol. Exp. Ther. 2004, 310, 263-271. [CrossRef]

53. Hardyman, J.E.; Tyson, J.; Jackson, K.A.; Aldridge, C.; Cockell, S.J.; Wakeling, L.A.; Valentine, R.A.; Ford, D. Zinc sensing by metal-responsive transcription factor 1 (MTF1) controls metallothionein and ZnT1 expression to buffer the sensitivity of the transcriptome response to zinc. Metallomics 2016, 8, 337-343. [CrossRef]

54. Troadec, M.B.; Ward, D.M.; Lo, E.; Kaplan, J.; De Domenico, I. Induction of FPN1 transcription by MTF-1 reveals a role for ferroportin in transition metal efflux. Blood 2010, 116, 4657-4664. [CrossRef]

55. Nose, Y.; Kim, B.E.; Thiele, D.J. Ctr1 drives intestinal copper absorption and is essential for growth, iron metabolism, and neonatal cardiac function. Cell Metab. 2006, 4, 235-244. [CrossRef]

56. Kim, H.; Son, H.Y.; Bailey, S.M.; Lee, J. Deletion of hepatic Ctr1 reveals its function in copper acquisition and compensatory mechanisms for copper homeostasis. Am. J. Physiol. Gastrointest. Liver Physiol. 2009, 296, G356-G364. [CrossRef]

57. Burk, R.F.; Hill, K.E.; Nakayama, A.; Mostert, V.; Levander, X.A.; Motley, A.K.; Johnson, D.A.; Johnson, J.A.; Freeman, M.L.; Austin, L.M. Selenium deficiency activates mouse liver Nrf2-ARE but vitamin E deficiency does not. Free Radic. Biol. Med. 2008, 44, 1617-1623. [CrossRef] 
58. Carlson, B.A.; Tobe, R.; Yefremova, E.; Tsuji, P.A.; Hoffmann, V.J.; Schweizer, U.; Gladyshev, V.N.; Hatfield, D.L.; Conrad, M. Glutathione peroxidase 4 and vitamin E cooperatively prevent hepatocellular degeneration. Redox Biol. 2016, 9, 22-31. [CrossRef]

59. Patterson, A.D.; Carlson, B.A.; Li, F.; Bonzo, J.A.; Yoo, M.H.; Krausz, K.W.; Conrad, M.; Chen, C.; Gonzalez, F.J.; Hatfield, D.L. Disruption of thioredoxin reductase 1 protects mice from acute acetaminophen-induced hepatotoxicity through enhanced NRF2 activity. Chem. Res. Toxicol. 2013, 26, 1088-1096. [CrossRef]

60. Suvorova, E.S.; Lucas, O.; Weisend, C.M.; Rollins, M.F.; Merrill, G.F.; Capecchi, M.R.; Schmidt, E.E. Cytoprotective Nrf2 pathway is induced in chronically txnrd 1-deficient hepatocytes. PLOS ONE 2009, 4, e6158. [CrossRef]

61. Li, Y.; Mo, X.; Xiong, Y. The Study on Polymorphism of TrxR and Nrf2/HO-1 Signaling Pathway in Kaschin-Beck Disease. Biol. Trace Elem. Res. 2018, 190, 303-308. [CrossRef]

62. Yim, S.H.; Clish, C.B.; Gladyshev, V.N. Selenium Deficiency Is Associated with Pro-longevity Mechanisms. Cell Rep. 2019, 27, 2785-2797 e3. [CrossRef]

63. Dong, R.; Wang, D.; Wang, X.; Zhang, K.; Chen, P.; Yang, C.S.; Zhang, J. Epigallocatechin-3-gallate enhances key enzymatic activities of hepatic thioredoxin and glutathione systems in selenium-optimal mice but activates hepatic Nrf2 responses in selenium-deficient mice. Redox Biol. 2016, 10, 221-232. [CrossRef]

64. Ma, S.; Lee, S.G.; Kim, E.B.; Park, T.J.; Seluanov, A.; Gorbunova, V.; Buffenstein, R.; Seravalli, J.; Gladyshev, V.N. Organization of the Mammalian Ionome According to Organ Origin, Lineage Specialization and Longevity. Cell. Rep. 2015, 13, 1319-1326. [CrossRef]

(C) 2019 by the authors. Licensee MDPI, Basel, Switzerland. This article is an open access article distributed under the terms and conditions of the Creative Commons Attribution (CC BY) license (http://creativecommons.org/licenses/by/4.0/). 